\title{
Soil Degradation Processes and Extreme Soil Moisture Regime as Environmental Problems in the Carpathian Basin
}

\author{
GY. VÁRALLYAY \\ Research Institute for Soil Science and Agricultural Chemistry (RISSAC) of the \\ Hungarian Academy of Sciences, Budapest
}

The most important element of sustainable development in the Carpathian Basin is the rational use and conservation of soil resources and ecosystems (the geological strata-soil-water-biota-plant-near surface atmosphere continuum), maintaining their favourable "quality" and desirable multifunctionality.

The natural conditions (climate, water, soil and biological resources) of the Carpathian Basin are generally favourable for rainfed biomass production (LÁNG et al., 1983; VÁRALLYAY et al., 1985). These conditions, however, show extremely high, irregular, consequently hardly predictable spatial and temporal variability, often extremes, and sensitively react to various natural or human-induced stresses. The main ecological constraints are:

1. Soil degradation processes.

2. Extreme moisture regime: simultaneous hazard of flood, waterlogging, overmoistening and drought sensitivity.

3. Unfavourable changes in the biogeochemical cycles of elements, especially of plant nutrients and environmental pollutants.

\section{Limiting Factors of Soil Fertility and Soil Degradation Processes}

There are large territories in the Carpathian Basin where the multifunctionality of soil is threatened and its fertility/productivity is limited by various soil properties and unfavourable/harmful soil degradation processes (SzABOLCS \& VÁRALLYAY, 1978; VÁRALLYAY, 1989a, 2000).

The limiting factors of soil fertility in Hungary are shown in Fig. 1 (SZABOLCS \& VÁRALLYAY, 1978). The "limitations" are even more serious in the nonHungarian part of the Carpathian Basin. Sustainable land use and soil management may react to these limitations in two different ways:

- adaptation to the given conditions by rational "site-specific" land use, proper cropping pattern and adequate agrotechnics;

Correspondence to: GYÖRGY VÁRALLYAY, Research Institute for Soil Science and Agricultural Chemistry of the Hungarian Academy of Sciences, H-1022 Budapest, Herman Ottó út 15. Hungary. E-mail: g.varallyay@rissac.hu 


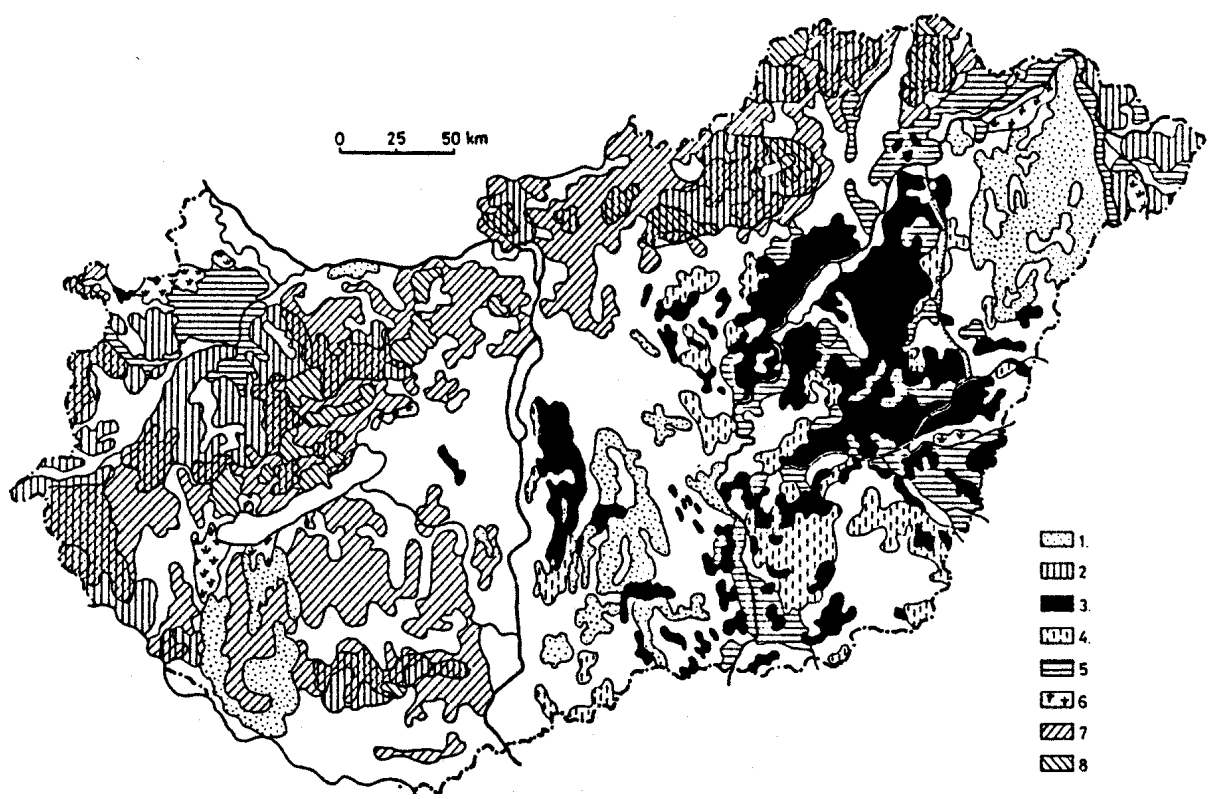

Fig. 1

Map of the limiting factors of soil fertility in Hungary. 1. Extremely coarse texture ( $8 \%$ of the total area of Hungary). 2. Acidity (12.8\%). 3. Salinity and/or alkalinity (8.1\%).

4. Salinity and/or alkalinity in the deeper layers (2.6\%). 5. Extremely heavy texture (6.8\%).

6. Waterlogging or peat formation (1.7\%). 7. Erosion (15.6\%). 8. Shallow depth $(2.3 \%)$.

- modification (improvement) of the unfavourable land-site conditions by amelioration.

Soil degradation is usually a complex process in which several features can be recognized that contribute to limitations in normal soil functions and may lead to serious environmental deterioration.

In spite of the large and increasing extension of degraded lands in all continents, it can be stated that soil degradation is not an unavoidable consequence of rational agricultural production and social development! Most soils are resilient to a certain extent, therefore, most of the soil degradation processes and their consequences can be efficiently prevented, eliminated or at least moderated. This, however, needs permanent control measures and widely adopted soil (and water) conservation technologies, which are the indispensable elements of sustainable (agricultural) development and up-to-date site-specific precision soil management (VÁRALLYAY, 2000, 2003).

In the Carpathian Basin the most important soil degradation processes are as follows (VÁRALLYAY, 1989a):

1. Soil erosion by water or wind.

2. Soil acidification.

3. Salinization/alkalization/sodification. 
4. Physical soil degradation, such as structure destruction, compaction, surface sealing, etc.

5. Extreme moisture regime: (sometimes) the simultaneous hazard of overmoistening, waterlogging and drought-sensitivity.

6. Biological degradation, such as unfavourable changes in soil biota, decrease in soil organic matter.

7. Unfavourable changes in the biogeochemical cycles of elements, especially in the regime of plant nutrients, such as leaching; volatilization; biotic and abiotic immobilization.

8. Decrease in the buffering capacity of soil, soil pollution, and environmental toxicity.

In the last years the revolutionary development of in situ and laboratory analytics, remote sensing, informatics, computer technology, GIS/GPS applications etc. gave opportunity for up-to-date database development, including all available soil information (description and data of soil survey, field experiments and measurements, laboratory analysis, remote sensing information, soil maps etc.) (SZABÓ et al., 1998; VÁRALLYAY, 2000, 2005d) and characteristics of environmental sensitivity/susceptibility of soils against various soil degradation processes.

\section{Limited Water Resources, Extreme Moisture Regime}

It is forecastable with good probability that in future water will be the determining (hopefully not limiting) factor of food security and environmental safety in the Carpathian Basin (PÁlfaI, 2000; SOMLYÓDY, 2000; VÁRAllYAY, 1989b). Consequently, the increase in water use efficiency and soil moisture control will be a key issue of sustainable development.

Water resources are limited in the Carpathian Basin. The increasing water demand must be satisfied from these limited resources. The average $450-600 \mathrm{~mm}$ annual precipitation may cover the water requirement of the main crops even at high yield levels. But the average shows extremely high, irregular and hardly predictable territorial (Fig. 2) and temporal (Fig. 3) variability - even at micro-scale. According to long-term meteorological forecasts ("global" climate change) the risk, probability, frequency, duration and intensity of extreme weather situations are expected to show an increasing tendency. Under such conditions a considerable part of the precipitation is lost by surface runoff, downward filtration and evaporation (VÁRALlYAY, 1989b, 2005b).

The annual water balance is negative in the Carpathian Lowland: $450-600 \mathrm{~mm}$ precipitation vs. $680-720 \mathrm{~mm}$ potential evapotranspiration. The negative water balance is equilibrated by horizontal inflow (on the surface as runoff; in the unsaturated zone as seepage; and in the saturated zone as groundwater flow), which leads to the accumulation of soluble constituents, the weathering products of a large water catchment area. In addition to the atmospheric precipitation pattern, the two additional reasons of extreme soil moisture regime (the simultaneous hazard of waterlogging or overmoistening and drought sensitivity) are: 
- the heterogeneous microrelief of the "flat" lowland;

- the highly variable, sometimes mosaic-like soil cover and the unfavourable physical and hydrophysical properties of some soils (Fig. 4).

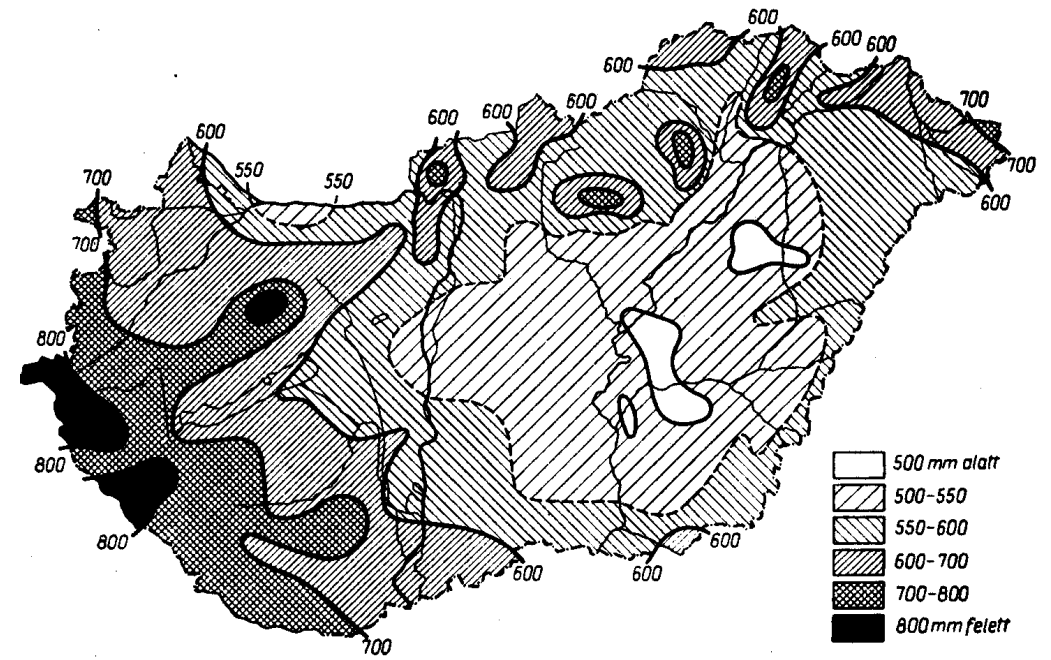

Fig. 2

Distribution of the amount of atmospheric precipitation in Hungary (long-term average)

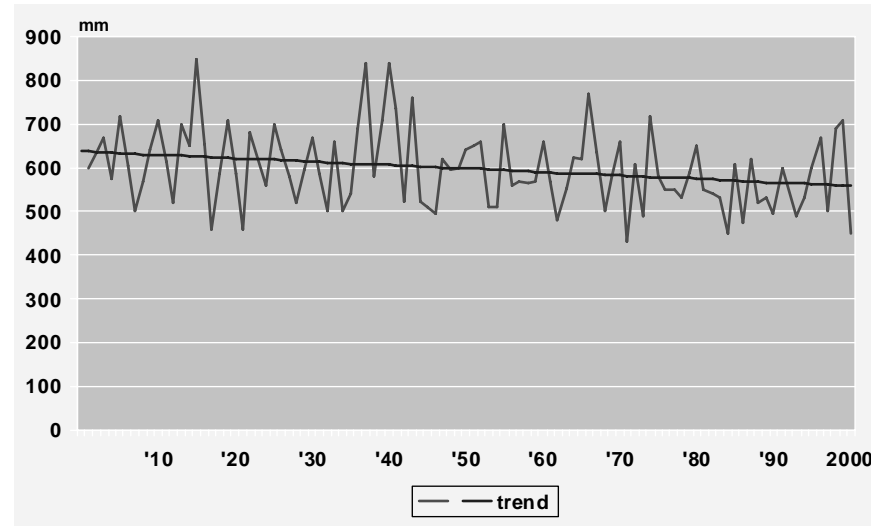

Fig 3

Long-term fluctuation of atmospheric precipitation in Hungary

Under such environmental conditions it is an important fact that soil is the largest potential natural water reservoir (water storage capacity) in Hungary (VÁRALLYAY, 2005a,c). The 0-100 cm soil layer may store about $25-30 \mathrm{~km}^{3}$ water, which is more than half of the average annual precipitation. About 50\% of it is ,available moisture content”. In many cases, however, this huge poten- 
Fig. 4

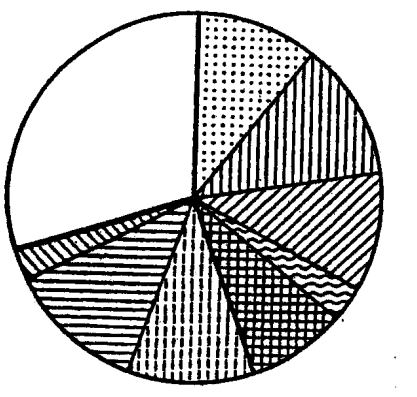

Distribution of soils according to their moisture regimes in Hungary. $1-5=$ Soils with unfavour$\square$ abou able hydrophysical properties $(43 \%)$ : 1: due to 国 very coarse texture $(10.5 \%) ; 2$ : due to very $\mathbf{W}_{2}$ heavy texture $(11 \%) ; 3$ : due to strong salinity3alinity (10\%); 4: due to waterlogging (3\%); 5: due to shallow depth $(8.5 \%) ; 6-8=$ Soils with i moderately unfavourable hydrophysical proper狊, ties $(26 \%)$ : 6 : due to coarse texture $(11 \%)$; 7: due to heavy texture or clay accumulation in the B-horizon (12\%); 8: due to moderate salinity/alkalinity in the deeper layers $(3 \%) ; 9=$ Soils with good hydrophysical properties $(31 \%)$

tial water storage capacity cannot be used because of four reasons (VÁrallyay, 2005a):

- it is not „empty”, it is filled up to a certain extent by a previous source of water (rain, melted snow, capillary transport from groundwater, irrigation etc.): "filled bottle effect";

- the infiltration of water into the soil is prevented by the frozen topsoil ("frozen bottle effect");

- the infiltration is prevented or reduced by a nearly impermeable soil layer on, or near to the soil surface ("closed bottle effect");

- the water retention of soil is poor and the infiltrated water is not stored in the soil, but only percolates through the soil profile ("leaking bottle effect").

The schematic map of these situations is presented in Fig. 5.

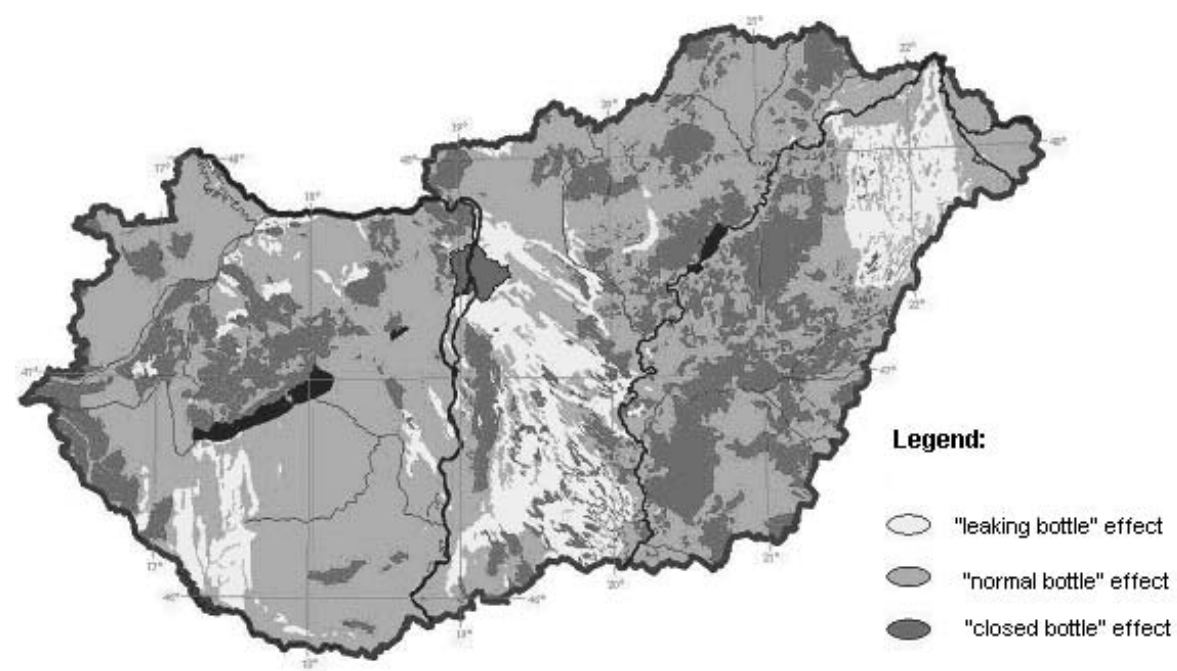

Fig. 5

Limited infiltration rate and water storage capacity of soils in Hungary 


\section{Significance of Soil Moisture Regime and its Database}

Soil moisture regime has particular significance both in soil fertility and environmental sensitivity (,vulnerability”).

In the last years a comprehensive soil survey-analysis-categorization-mappingmonitoring system was developed in Hungary for the exact characterization of hydrophysical properties, modelling and forecast of water and solute regimes of soils. The system may serve as a scientific basis for soil moisture control and it is efficiently used for practical soil water management both for crop production and environmental protection. The most important elements of the system were as follows:

a) Category system and 1:100 000 scale map of the hydrophysical characteristics of soils (VÁrALLYAY, 1989c, 2005a; VÁRALlyAY et al., 1985): Fig. 6.

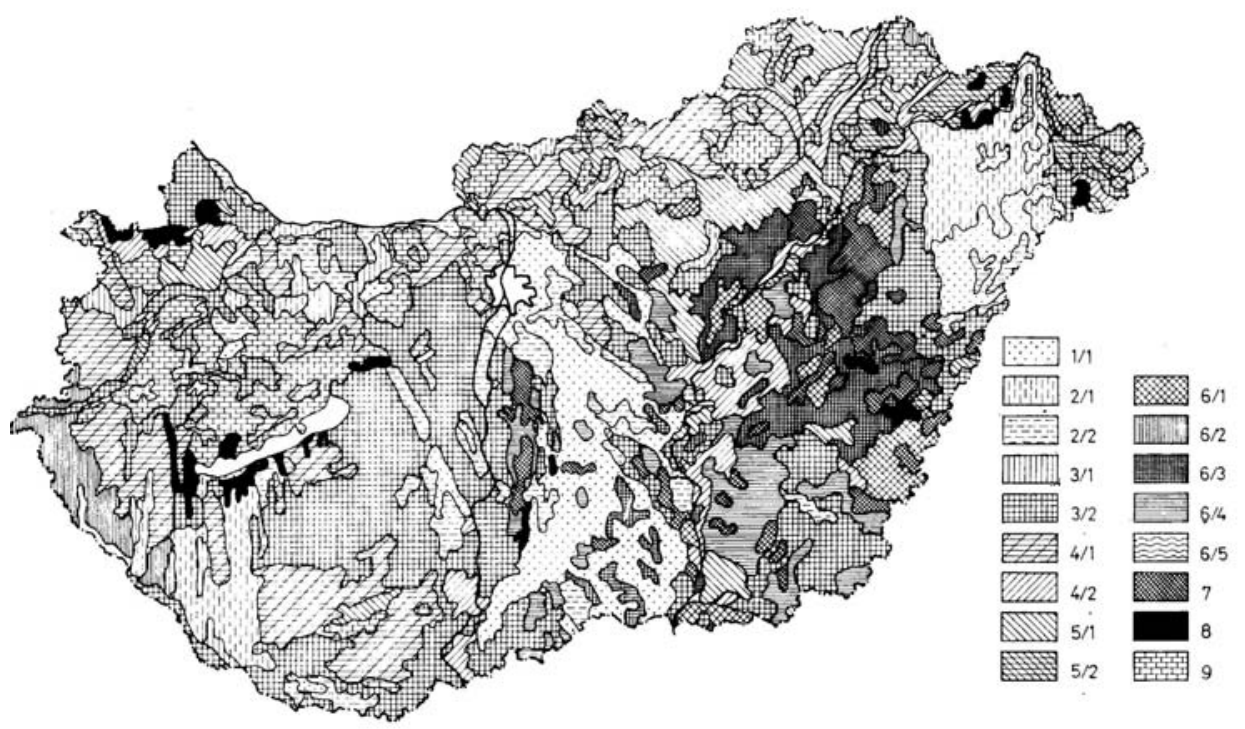

Figure 6. Hydrophysical characteristics of soils in Hungary

The 9 main soil water categories are as follows: 1 . Soils with very high infiltration rate (IR), permeability (P) and hydraulic conductivity (HC); low field capacity (FC); and very poor water retention (WR). 2. Soils with high IR, P and HC; medium PC; and poor WR. 3. Soils with good IR, P and HC; good FC; and good WR. 4. Soils with moderate IR, P and HC; high FC; and good WR. 5. Soils with moderate IR, poor P and HC; high PC and high WR. 6. Soils with unfavourable water management: low IR, extremely high WR. 7. Soils with extremely unfavourable water management: very low IR, extremely low P and HC; and very high WR. 8. Soils with good IR, P and $\mathrm{HC}$; and very high FC. 9. Soils with extreme moisture regime due to shallow depth. The main profile variants: (1) texture becomes lighter with depth (soils formed on relatively light-textured parent material): $2 / 1,3 / 1$. (2) uniform texture within the profile: $1 / 1,2 / 2,3 / 2,4 / 2,5 / 2$. (3) relative clay accumulation in the horizon B: 4/1, 4/1. Profile variants of category $6: 6 / 1$ : heavy-textured soils with poor structure and a compact layer formed under the influence of misguided soil management; $6 / 2$ : pseudogleys; $6 / 3$. deep meadow solonetzes, solonetzes turning into steppe formation and solonetzic meadow soils (with an A horizon thicker than $15 \mathrm{~cm}$ ); 6/4: soils with salinity/alkalinity in the deeper horizons 
b) Moisture regime types of Hungarian soils and their 1:100 000 scale map (VÁRALlYAY, 1985):

1. Heavy surface runoff.

2. Heavy downward flow.

3. Moderate downward flow.

4. Equilibrium type.

5. Rapid filtration type (light-textured soils).

6. Groundwater-wetted type (upward flow is dominant).

7. Extreme moisture regime due to salinity-alkalinity.

8. Extreme moisture regime due to shallow depth.

9. Soils under the influence of rivers and surface streams.

10. Regularly waterlogged areas.

11. Forest with special moisture regime.

c) Large-scale (1:10000-1:25000) mapping of hydrophysical properties and moisture regime of soils (VÁRALLYAY, 1989c). From the successful practical application of the comprehensive soil database in soil moisture control two "case studies" can be mentioned:

1. The development of a category system for the characterization of the waterlogging hazard from the viewpoint of soil conditions. The prognosis has been totally proven by the 2003, 2005 and 2006 waterlogging events.

2. The elaboration of a 5-step model system (VÁRALLYAY \& RAJKAI, 1989) for the exact and quantitative description of moisture flow and solute transport within layered soil profiles above a fluctuating groundwater table; and for the estimation of the quantity of water and soluble constituents entering the soil profile from the groundwater by capillary transport. The model was efficiently used for the determination of the "optimum depth" (ensuring additional moisture supply for plants from the good-quality groundwater) and the "critical depth" (preventing salt accumulation, salinization-alkalization from saline, poor-quality groundwater) of the water table (SZABOlCS et al., 1969; VÁRALLYAY, 1974) in the planning and establishment of water regulation systems both in the Danube Lowland and in the Tisza Plain, respectively.

\section{Control of Soil Degradation Processes and Soil Moisture Regime}

The multifunctionality of soil is determined by the combined influences of soil properties, which are the results of soil processes (mass and energy regimes, abiotic and biotic transport and transformation, and their interactions) under the combined influences of soil forming factors (VÁRALLYAY, 2003). Any soil-related human activity influences the soil through these processes. Consequently, the control of soil processes is a great challenge and the main task of soil science and soil management in sustainable development.

In sustainable land use and site-specific soil management yield stability, risk reduction, soil conservation, and the prevention, elimination or moderation of extreme moisture situations have great significance and soil moisture control is of primary 


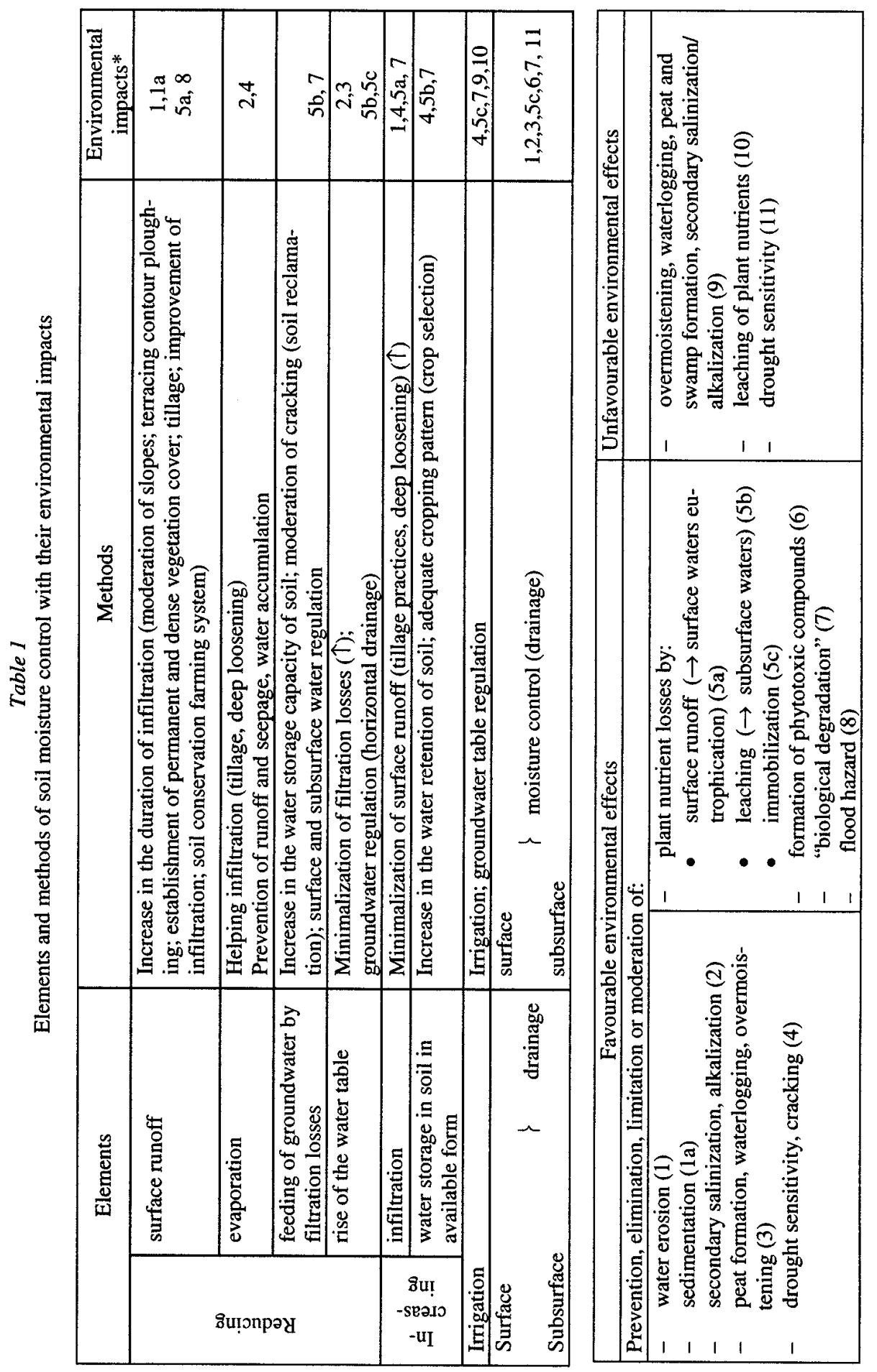


importance. In the Carpathian Basin it requires a "two-way" ("double-faced") moisture regulation to:

- help water infiltration into the soil;

- help water storage within the soil in plant available form;

- drain the surplus amount of water from the soil profile and from the area (vertical and horizontal drainage).

The main possibilities and methods of this moisture control are summarized in Table 1. Most of these "moisture management actions" are - at the same time efficient environment control measures (Table 1).

\section{Conclusions}

Sustainable land use and rational soil management, including an up-to-date soil moisture control requires continuous actions. This permanent control may prevent, eliminate or at least reduce undesirable soil processes and their harmful economi$\mathrm{cal} /$ ecological/environmental/social consequences; utilizing the unique soil characteristic, resilience, may satisfy the conditions for the "quality maintenance" of this "conditionally renewable" natural resource.

Control can be efficient only on the basis of comprehensive risk assessment, impact analysis and exact prognosis. These have to be the main research priorities!

The successful prevention, elimination or moderation of undesirable soil degradation processes and extreme moisture regimes can be efficient only in a wellcoordinated multidisciplinary international cooperation in the Carpathian Basin. The realization of the sustainability concept in the rational land use and soil management gives reality for a better life: healthy, good quality food, clean water and pleasant environment.

Key words: soil degradation, hydrophysical properties, moisture regime, water storage capacity, moisture control

\section{References}

LÁNG, I., CSETE, L. \& HARNos, Zs., 1983. Agro-ecological potential of Hungarian agriculture. (In Hungarian) Mezőgazdasági Kiadó. Budapest.

PÁlfaI, I. (Ed.), 2000. The role and significance of water in the Hungarian Plain. (In Hungarian) Nagyalföldi Alapítvány. Békéscsaba.

SOMLYÓDY, L., 2000. Strategy of Hungarian water management. (In Hungarian) MTA Vízgazdálkodási Tudományos Kutatócsoportja. Budapest.

SZABÓ, J. et al., 1998. Integration of remote sensing and GIS techniques in land degradation mapping. Agrokémia és Talajtan. 47. 63-75.

SZABOlCS, I. \& VÁRALlYAY, GY., 1978. Limiting factors of soil fertility in Hungary. (In Hungarian) Agrokémia és Talajtan. 27. 181-202. 
Szabolcs, I., DARAB, K. \& VÁRAllyay, Gy., 1969. Methods for the prognosis of salinization and alkalization due to irrigation in the Hungarian Plain. Agrokémia és Talajtan. 18. Suppl. 351-376.

VÁrallyay, Gy., 1974. Hydrophysical aspects of salinization from the groundwater. Agrokémia és Talajtan. 23. Suppl. 29-44.

VÁRALLYAY, GY., 1985. Main types of water regimes and substance regimes in Hungarian soils. (In Hungarian) Agrokémia és Talajtan. 34. 267-298.

VÁRAllyay, Gy., 1989a. Soil degradation processes and their control in Hungary. Land Degradation and Rehabilitation. 1. 171-188.

VÁRAllyay, GY., 1989b. Soil water problems in Hungary. Agrokémia és Talajtan. 38. 577-595.

VÁRALlYAY, GY., 1989c. Mapping of hydrophysical properties and moisture regime of soils. Agrokémia és Talajtan. 38. 800-817.

VÁRALLYAY, GY., 2000. Risk assessment and prevention of soil degradation processes in Hungary. In: Foresight and Precaution. (Eds.: CotTAM et al.). 563-567. Balkema. Rotterdam.

VÁRALLYAY, GY., 2003. Role of soil multifunctionality in future sustainable agricultural development. Acta Agronomica. 51. (1) 109-124.

VÁRALlYAY, GY., 2005a. Water storage capacity of Hungarian soils. (In Hungarian) Agrokémia és Talajtan. 54. 5-24.

VÁRALlYAY, GY., 2005b. Soil water management and the environment. (In Hungarian) In: A talaj vízgazdálkodása és a környezet. (Ed.: NÉMETH, T.) 15-30. MTA TAKI. Budapest.

VÁRALlYAY, GY., 2005c. Soil physical/hydrophysical characteristics and extreme moisture events in Hungary. In: Review of Current Problems in Agrophysics. (Eds.: JozefaciuK, G., Slavinski, C. \& WalCZAK, R. T.) 323-329. Institute of Agrophysics. P. A. N. Lublin.

VÁRAllyay, Gy., 2005d. Soil survey and soil monitoring in Hungary. In: Soil Resources of Europe. (Eds.: JONES, R. J. A. et al.) 169-179. ESB Research Report No. 9. ( $2^{\text {nd }}$ ed.) JRC. Ispra, Italy.

VÁRAllyAY, GY. \& RAJKAI, K., 1989. Model for the estimation of water and solute transport from the groundwater to the overlying soil horizons. Agrokémia és Talajtan. 38. 641-656.

VÁRALLYAY, GY. et al., 1985. Soil factors determining the agroecological potential of Hungary. Agrokémia és Talajtan. 34. Suppl. 90-94. 